\title{
DIVERSE APPROACHES TO TOTAL AND PARTIAL IN ABSENTIA TRIALS BY INTERNATIONAL CRIMINAL TRIBUNALS
}

\begin{abstract}
In the history of international criminal justice, the in absentia trial has always sparked some lively debates. Both the International Military Tribunals (IMTs) in Nuremberg and Tokyo recognized the in absentia trial and in Nuremberg one accused was actually convicted in his absence. However, ideas on holding trials in the absence of the accused have changed over time and international criminal tribunals established after the IMTs adopted the opposite approach; i.e. they rejected the in absentia trial as not being consistent with the accused's fair trial rights. Nonetheless, the latest addition to the list of international criminal tribunals, the Special Tribunal for Lebanon, surprisingly reintroduced the concept of the in absentia trial as a means to preclude suspects of international crimes to avoid justice. Moreover, recently there have also been international cases in which the accused was absent from the proceedings against him; i.e. the accused refused to enter the courtroom as he did not recognize the legitimacy of the court or requested permission not to attend the hearings in light of his demanding responsibilities at home that are linked with his high level position. The question what the concept of in absentia trials - both total and partial really entails and whether, and if so how, in absentia trials are permitted in international criminal law are the subject of discussion in this contribution.
\end{abstract}

\section{INTRODUCTION}

In the history of international criminal justice, the concept of in absentia trials has always sparked some lively debates. Both the International Military Tribunals (IMTs) in Nuremberg and Tokyo recognized the in absentia trial. The IMT in Nuremberg, accordingly, sentenced one of its

\footnotetext{
* Mohammad Hadi Zakerhossein is a PhD Researcher in international criminal law at Tilburg University, The Netherlands.

**Anne-Marie de Brouwer is an Associate Professor in international criminal law and a research fellow with the International Victimology Institute Tilburg (INTERVICT) at Tilburg University.E-mail: m.h.zakerhossein@uvt.nl; a.1.m.debrouwer@uvt.nl
} 
accused, Bormann, to death, while he was absent from the proceedings. However, this permissive approach to the in absentia trial changed over time and other international criminal tribunals since Nuremberg adopted therefore the opposite approach; i.e. holding that an in absentia trial is not being consistent with the accused's fair trial rights and thus not allowed. Nonetheless, the latest addition to the list of international criminal tribunals, the Special Tribunal for Lebanon (STL), reintroduced the concept of in absentia trials as a means to preclude suspects of international crimes to avoid justice.

Before the other international criminal tribunals and courts, i.e. ICTY, ICTR, SCSL, SPSC, ECCC and ICC, ${ }^{1}$ the prohibition of conducting an in absentia trial did not put an end to the challenges either. Even when the accused is under the control of the tribunal, some challenges may arise. For example, accused may disrupt the proceedings so that judges will have to remove them from the courtroom. Some defendants may suffer from bad health conditions and are therefore not able to attend the hearings. Moreover, some defendants prefer to be absent from the ongoing hearings. The International Criminal Court (ICC or Court) has been faced with this latter situation, when Kenyatta and Ruto - the President and Deputy President of Kenya, respectively, and both accused before the ICC - requested the Court that they would not have to attend the hearings in their cases in light of their demanding duties that their positions demand.

The above mentioned different approaches to the in absentia trial are also reflected in the literature and in particular the adoption of the in absentia trial by the STL puts this issue at the heart of academic attention. However, this contribution makes some valuable contributions to the already existing literature. First of all, from a conceptual perspective, this contribution provides further clarification on the notion of the in absentia trial. Although a conceptual question should normally precede a normative question, this first step is oftentimes taken for granted. Second of all, recent developments that took place before the ICC with respect to the notion of in absentia trials have mostly been absent from analyses and are extensively discussed in this contribution.

Before going into further detail, some clarifications on the term 'in absentia trial' are necessary. The term is not a straightforward and subtle expression. As Jenks stated: 'the concept of in absentia

\footnotetext{
${ }^{1}$ ICTY stands for "International Criminal Tribunal for the former Yugoslavia"; ICTR stands for "International Criminal Tribunal for Rwanda"; SCSL stands for 'Special Court for Sierra Leone'; SPSC stands for 'Special Panel for Serious Crimes (East Timor)'; ECCC stands for 'Extra-ordinary Chambers in the Courts for Cambodia'; ICC stands for 'International Criminal Court.'
} 
proceedings seems to mean different things to different people.' ${ }^{2}$ Both components of the expression 'in absentia trial,' namely 'in absentia' and 'trial,' need therefore to be defined and clarified. Literally speaking, 'in absentia' means 'in the absence of.' However, as Pons asserted 'in international law, it is not yet entirely clear what the notion of absentia really means and in what circumstances the accused may be considered to have the legal status of 'absent' from trial. ${ }^{3}$

The word 'in absentia,' in the context of an 'in absentia trial,' refers to a trial where the accused is absent or, in other words, is not present. The standard to determine the presence or the absence of the accused is his physical presence in the courtroom during a trial. ${ }^{4}$ However, as will be discussed later, an in absentia trial in its normative meaning refers to the prohibition of a trial in the absence of an effective defence, which is mostly accompanied with the physical absence of the accused.

Moreover, the word 'trial,' in the context of the in absentia trial, does not carry one meaning only. Firstly, 'trial' may refer to the criminal proceedings as a whole, from its investigation phase to its sentencing stage. In this context, the accused is convicted without his defence is heard. In addition, the accused's sentence remains pending due to his absence. Secondly, the word 'trial' may refer to only a session or hearing of the total proceedings. Therefore, the expression of 'in absentia trial' includes two instances. In the first place it can refer to 'a total in absentia trial' in which the accused is completely absent from the criminal proceedings, which is also called 'trial by default." In the second place it can refer to 'a partial in absentia trial,' where the accused is absent in one or some specific hearings, while he is still under the control of the court in order to undergo a sentence, if found guilty. Here, the reasons for the absence of the accused can be various. The accused may waive his right to be present at trial, may be removed from the courtroom due to his disruptive behavior, or the health status of the accused may hamper his presence in the courtroom.

\footnotetext{
${ }^{2}$ C. Jenks, 'Notice Otherwise Given: Will in Absentia Trials at the Special Tribunal For Lebanon Violate Human Rights?', (2009) 33 Fordham International Law Journal 56, 68.

${ }^{3}$ N. Pons, 'Some Remarks on in Absentia Proceedings before the Special Tribunal for Lebanon in Case of a State's Failure or Refusal to Hand over the Accused', (2010) 8 Journal of International Criminal Justice 1307, 1309.

${ }^{4}$ Where, in this contribution, we refer to 'his' we also refer to 'her.'

${ }^{5}$ P. Gaeta, 'To Be (Present) or Not To Be (Present)', (2007) 5 Journal of International Criminal Justice 1165, 1169.
} 
In spite of this conceptual distinction, the legal literature tends to lump different types of in absentia trials together and study them from a normative perspective. This leads to some incoherence and misunderstanding as to the phenomenon. This publication recognizes, however, the above distinction of total and partial in absentia trials and aims to answer whether total and partial in absentia trials are prohibited or permitted in proceedings before international criminal tribunals, and if permitted, under which circumstances. The diverse approaches to the issue of in absentia trials that can be found when studying the legal frameworks and practices of international criminal tribunals - including the IMTs, ICTY, ICTR, SCSL, SPSC, ICC and STL - are addressed in this publication. The first section focuses on the total in absentia trials, the second section on the partial in absentia trials, and finally, in the third section, our preliminary conclusions on this topic are given.

\section{TOTAL IN ABSENTIA TRIALS}

The total in absentia trial has a colorful history in the context of international criminal proceedings. Although the prohibition of total in absentia trials is largely agreed upon in proceedings before the international criminal tribunals, it is interesting to note that the first and latest established tribunals - i.e. the IMT for Nuremberg and the Special Tribunal for Lebanon - both adopted this mechanism as a legitimate feature to fulfill their mandates.

\subsection{Approaches by International Criminal Tribunals}

In the following sub-paragraphs the different approaches by international criminal tribunals to the issue of total in absentia trials will be set out, i.e. the IMTs, ICTY, ICTR, SCSL, SPSC, ICC and the STL.

\subsubsection{The IMT and the IMTFE}

Despite the fact that the IMT in Nuremberg suffered from evident drawbacks, the Tribunal proved to be the foundation of what has now become modern international criminal justice. ${ }^{6}$ From the beginning, the Allies - the USA, UK, France and Russia - adopted a policy with respect to the selection of defendants to focus on those

\footnotetext{
${ }^{6}$ R. Overy, 'The Nuremburg Trials: International Law in the Making?' in P. Sands (ed.), From Nuremburg to The Hague: The Future of International Criminal Justice (Cambridge: Cambridge University Press, 2003), 2.
} 
suspects who were in the custody of the founding states (the Allies) of the Tribunal already. The reason behind this policy was to preserve the reputation and effectiveness of the Tribunal. Such a policy served the interests of the founding states to show their power and ability to bring the defendants to justice. This policy was enshrined in a remark made by the then Attorney-General of the UK, Sir Hartley Shawcross, at a meeting in June 1945. He said that to draw up another list of defendants: "the test should be: Do we want the man for making a success of our trial? If yes, we must have him. ${ }^{77}$ The Allied powers therefore only tried those individuals they knew they would be able to get their hands on.

Despite this fact, the governing law of the Tribunal allowed for total in absentia trials. Article 12 of the Nuremberg IMT Charter stated that 'The Tribunal shall have the right to take proceedings against a person charged with crimes set out in Article 6 of this Charter in his absence, if he has not been found or if the Tribunal, for any reason, finds it necessary, in the interests of justice, to conduct the hearing in his absence.' This provision is remarkable because it was a departure from the legal tradition that had been adopted by two founding states of the tribunal, namely the USA and the UK, as common law system holders. Cassese pointed to the extreme gravity of the crimes committed by the defendants of the Tribunal as a justification for this departure. ${ }^{8}$ However, it seems that also another justification existed as total in absentia trials are considered to be a feature of the civil law systems. The incorporation of a feature of civil law into the law of the Nuremberg Tribunal was probably a compromise to overcome the discontent of another founding member, namely France. As Overy asserted: 'French lawyers were unhappy with a tribunal whose main basis was to be Anglo-Saxon common law instead of Roman law, and whose procedures were foreign to French legal practice. ${ }^{9}$

Nevertheless, the possibility of having a total in absentia trial before the Nuremberg Tribunal was conditional. According to Rule 2(b) of the Rules of Procedure: 'any individual defendant not in custody shall be informed of the indictment against him.' Giving notice to the suspect is a condition that is in common with national systems that recognize a total in absentia trial as an applicable me-

\footnotetext{
${ }^{7}$ Ibid., 8 .

${ }^{8}$ A. Cassese, International Criminal Law (Oxford: Oxford University Press, 2008), 367.

${ }^{9}$ Overy (n 6 above), 22.
} 
chanism. In these (civil law) jurisdictions it is believed that the accused at large waives his right to be present at trial if he has already been informed about the ongoing proceedings against him and does not appear in court.

In spite of the possibility of holding a total in absentia trial at the Nuremberg Tribunal, this possibility was only once used, namely in the case of Martin Bormann, the former head of the Nazi Party Chancellery and Hitler's private secretary. ${ }^{10}$ In this case, in compliance with Rule 2(b), public notice about the upcoming trial was given via newspapers and the radio in October and November 1945 to notify Bormann of the proceedings against him. ${ }^{11}$ In addition, Bergold was appointed as counsel for the accused. Bergold challenged the in absentia trial of his client. His challenge was, however, not based on the illegitimacy of the total in absentia trial; he instead claimed that his client was already dead. ${ }^{12}$ However, the Tribunal expressed in its Judgment, issued on 1 October 1946, that 'the evidence of death is not conclusive and the tribunal, as previously stated, is determined to try him in absentia. If Bormann is not dead and is later apprehended, the Control Council for Germany may under article 29 of the Charter, consider any facts in mitigation, and alter or reduce his sentence, if deemed proper. ${ }^{13}$ Bormann was convicted of war crimes and crimes against humanity and finally sentenced to death by hanging on 15 October 1946. He was, however, never found and, as a result, his sentence remained outstanding. It was later discovered that he was in all probability already dead while his trial was ongoing. ${ }^{14}$

Finally, to be comprehensive, it should be noted that the Charter of the IMT for the Far East (IMTFE or Tokyo Tribunal) did not provide for any specific provision with respect to in absentia trials.

\footnotetext{
${ }^{10}$ A. Klerks, Trials in Absentia in International Criminal Law (Tilburg University, Master thesis, 2008), 18.

${ }^{11}$ J. McGovern, Martin Bormann (New York: Littlehampton Book Services Ltd, 1968), 167-168.

${ }^{12}$ For more information about the challenge posed by Bergold see: W. A. Schabas, 'In Absentia Proceedings before International Criminal Courts' in G. Sluiter and S. Vasiliev (eds.), International Criminal Procedure: Towards a Coherent Body of Law (London: Cameron May Publishing, 2009), 339-342.

${ }^{13}$ Judgment of the International Military Tribunal for the Trial of German Major War Criminals, Nuremberg, 30 September and 1 October 1946.

${ }^{14}$ I. Karacs, 'DNA test closes book on mystery of Martin Bormann', The Independent, 4 May 1998.
} 
Klerks argues that since Article 9 of the Tokyo Tribunal's Charter on the notion of a fair trial - did not include a right to be present at trial, an in absentia trial was theoretically allowed before this Tribunal. ${ }^{15}$ In any case, the Tribunal never made use of this possibility in practice.

\subsubsection{The ICTY and the ICTR}

The Statutes of the ad hoc Tribunals - the ICTY and the ICTR - do not embrace a provision that explicitly addresses the in absentia trial. However, the right to be present at trial is enshrined in both Statutes, in common Article 21(4)(d). According to this provision, the accused shall be entitled to 'be tried in his presence, and to defend himself in person or through legal assistance of his own choosing.' Therefore, it can be said that 'total in absentia trials' are not allowed at the ad hoc Tribunals. This perception is consistent with the remarks of the then UN SecurityGeneral, Boutros Boutros-Ghali, in his report of 3 May 1993 to the UN Security Council with respect to the ICTY. In this report he held that 'a trial should not commence until the accused is physically present before the International Tribunal. There is a widespread perception that trials in absentia should not be provided for in the [ICTY] statute as this would not be consistent with article 14 of the ICCPR. ${ }^{16}$

Nonetheless, the Rules of Procedure and Evidence (RPE) of both the ICTY and the ICTR provide for a procedure in case of failure to execute a warrant of arrest, namely Rule 61 . Sometimes, this procedure is considered as an in absentia trial and as a compromise between the different views of the civil and common law systems with respect to in absentia proceedings. ${ }^{17}$ However, it seems that the emergence of Rule 61 is not only the result of a compromise between different legal and theoretical perspectives, but that it was also created for its practical necessity and advantages to ensure the effective functioning of the Tribunals. Contrary to the ICTY, however, no proceedings have ever been conducted under Rule 61 before the ICTR. ${ }^{18}$

\footnotetext{
15 Klerks (n 10 above), 18.

${ }^{16}$ The UN Secretary-General, Report of the Secretary-General Pursuant to Paragraph 2 of Security Council Resolution 808 (1993), (U.N. Doc. S/25704), 3 May 1993, para. 101.

${ }^{17}$ W. A. Schabas, An Introduction to the International Criminal Court (Cambrideg: Cambridge University Press, 2010), 289.

${ }^{18}$ B. Elberling, The Defendant in International Criminal Proceedings: Between Law and Historiography (Portland: Hart Publishing, 2012), 48.
} 
What does a Rule 61 procedure entail? Rule 61 is not a trial proper; instead it is a reconfirmation of the indictment. In the words of the Trial Chamber of the Special Tribunal for Lebanon, when commenting on common Rule 61 of the ICTY and ICTR RPE: 'it is a procedure in absentia but not a trial in absentia. ${ }^{19}$ Indeed, it is merely a pre-trial mechanism and that is why Rule 61 does not allow for a determination of the accused's guilt. ${ }^{20}$ Rule 61 is applicable 'where the arrest warrant, which was issued after the indictment was confirmed by one judge, has not been executed and where because of the non-execution of the arrest warrant, the indictment has not been served to the accused.' In such a case, the Prosecutor shall satisfy the judge, who had already confirmed the indictment, that all reasonable steps have been taken to secure the arrest of the accused and to ascertain his whereabouts, but that they have not resulted in an arrest. Then, if the judge is satisfied, he shall order the Prosecutor to submit the indictment to the Trial Chamber. In this case, the Prosecutor submits the indictment and the collected evidence in an open and public court. ${ }^{21}$ Afterwards, pursuant to Rule 61(d), the Trial Chamber will issue an 'international arrest warrant' that will be transmitted to all states, if the Chamber determines that there are reasonable grounds to believe that the accused has committed the charges made against him.

Due to the publicity feature of the Rule 61 hearing, many benefits can be identified for this mechanism. It serves a pedagogic purpose in the sense that it highlights the heinousness of the crimes committed by the accused and the key role of the Tribunal to combat those atrocities. ${ }^{22}$ In addition, such a mechanism gives great leverage to the Tribunal to protect its reputation. It shows to the public that the Tribunal, on behalf of the international community, is not passive; on the contrary, that it is actively trying to administer justice. Former ICTY Judge Sidhwa, in that light, mentioned that: 'Rule 61 is basically an apology for this Tribunal's helplessness in not being able to

${ }^{19}$ Prosecutor v. Ayyash et al, (Decision to Hold Trial In Absentia) STL-11/01/I/TC (1 February 2012), para. 37.

${ }^{20}$ C. Paulussen, Male Captus Bene Detentus: Surrendering Suspects to the International Criminal Court (Antwerp - Oxford: Intersentia, 2010), 367.

${ }^{21}$ K. Ambos and S. Bock, 'Procedural Regimes' in L. Reydams, J. Wouters and C. Ryngaert, (eds.), International Prosecutors (Oxford: Oxford University Press, 2010), 506.

${ }^{22}$ L. Chand Vohrah, 'Pre-Trial Procedures and Practices' in: G. Kirk McDonald and O. Swaak-Goldman (eds.), Substantive and Procedural Aspects of International Criminal Law: The Experience of International and National Courts, Volume I (The Hague: Kluwer Law International, 2000), 504. 
carry out its duties, because of the attitude of certain states that do not want to arrest or surrender accused persons, or even to recognize or cooperate with the Tribunal. In such circumstances, it is the International Tribunal's painful and regrettable duty to adopt the next effective procedure to inform the world, through open public hearings, of the terrible crimes with which the accused is charged and the evidence against the accused that would support his conviction at trial. ${ }^{, 23}$ This mechanism is also considered to be "the voice of the victims. ${ }^{24}$ Indeed, the victims, through this procedure, are given an opportunity to speak out and to give their testimony in open court, which may, for some, contribute to their healing process. ${ }^{25}$ One can say that for the victims, in the context of international criminal justice, the process may be at least as important as the result. Therefore, one of the most convincing remedies for victims of international crimes is that they can see that they are listened to and that justice is done. ${ }^{26}$

To conclude, Rule 61 may be seen as a reasonable and pragmatic compromise in the context of the ICTY and ICTR's proceedings in order to cope with the problem arising from the lack of control over the accused, when an in absentia trial is not permitted.

\subsubsection{The SCSL, SPSC and the ECCC}

Hybrid or internationalized tribunals, such as the SCSL, SPSC and the ECCC, have adopted a common policy with respect to in absentia trials; in principle they do not accept total in absentia trials. However, if the accused is initially present and then flees or refuses to appear in court, the procedural law of these Tribunals prescribes that the trial will be carried out in the absence of the accused. This kind of in absentia trials is very similar to total in absentia trials, because the accused is absent at the sentencing stage of the proceedings. Rule 60(a) of the Rules of Procedure and Evidence of the SCSL specifically provides that an accused may be tried in his absence if: '(i) the accused has made his initial appearance, has been afforded the right to appear at his own trial, but refuses so to do; or ii) the accused, having made his initial appearance, is at large and refuses to appear in court.' Subparagraph (b) adds 'In either case the accused may be represented by counsel of his choice, or as directed by a Judge or Trial Chamber.

${ }^{23}$ Prosecutor v. Rajic, (Separate Opinion of Judge Sidhwa, Rule 61 Decision) IT95-12-TC (13 September 1996), para. 7.

${ }^{24}$ Ibid.

${ }^{25}$ Klerks (n 10 above), 27.

${ }^{26}$ Ibid. 
The matter may be permitted to proceed if the Judge or Trial Chamber is satisfied that the accused has, expressly or impliedly waived his right to be present.' In the case of Augustine Gbao known as the Third Accused and prosecuted alongside Issa Hassan and Morris Kallon - Gbao, following his initial appearance, refused to attend the courtroom again, because he did not recognize the legitimacy of the court. The Trial Chamber decided to proceed with the ongoing trial against the accused as, by refusing to reappear in court, he waived his right to be present. The Chamber in its decision of 12 July 2004, mentioned 'though in essence trial in the absence of an accused person is an extraordinary mode of trial, yet it is clearly permissible and lawful in very limited circumstances. ${ }^{27}$ It came to the conclusion that 'this Court is satisfied that the Third Accused has expressly waived his right to be present at his trial and this Court has no other option but to permit the joint trial of all the three accused persons to proceed in the absence of the Third Accused pursuant to Rule 60(A)(i) of the Rules and it is so ordered. ${ }^{28}$

Similarly, before the SPSC, Rule 5(2) of the Transitional Rules of the Criminal Procedure, adopted by the UN Transitional Administration in East Timor, allowed in absentia proceedings if the accused was initially present and then fled or was otherwise voluntarily absent. ${ }^{29}$ However, it seems that in absentia trials have not taken place before the SPSC.

Similarly, Rule 81(4) of the Internal Rules of the ECCC embraces the idea that in absentia trials are only allowed when, after the initial appearance of the accused in court, the accused refuses or fails to appear at or is expelled from subsequent court proceedings. ${ }^{30}$ With respect to the ECCC, it is interesting to note that initially draft Rule

${ }^{27}$ Prosecutor v. Issa Hassan, Morris Kallon and Augustine Gbao, (Ruling on the issue of the refusal of the Third Accused, Augustine Gbao, to attend hearings of the Special Court for Sierra Leone on 7 July 2004 and succeeding days) SCSL-04-15-T (12 July 2004), para. 8.

${ }^{28}$ Ibid., para. $12(1)$.

${ }^{29}$ Rule 5(2) reads as follows: 'If at any stage following the hearing provided in Section 29.2 of the present regulation the accused flees or is otherwise voluntarily absent, the proceedings may continue until their conclusion.'

${ }^{30}$ Rule 81(4) Internal Rules ECCC reads as follows: 'If the accused, following an initial appearance and having been duly summoned to the subsequent hearing, continues to refuse or fails to attend the proceedings, or is expelled from them in accordance with these IRs, the proceedings may continue in his or her absence. In such cases, the accused may be defended during the proceedings by his or her lawyer. Where the accused refuses to choose a lawyer, the Chamber shall order that the 
79(1) proposed to prohibit inabsentia trials. This proposition was welcomed by human rights NGOs that considered such a prohibition in consistency with human rights norms. ${ }^{31}$ Nonetheless, in the final draft, Rule 81(1) stated that: ' 1 . The accused shall be tried in his or her presence, except as provided in this Rule.'

With respect to the ECCC case law, there is an interesting precedent covering the issue of in absentia trials. One of the ECCC's accused was Ieng Sary, the then Deputy Prime Minister for Foreign Affairs in the reign of Khmer Rouge. Following the collapse of the terror regime in 1979, he fled to Thailand and was then convicted of genocide and sentenced to death in absentia by the People's Revolutionary Tribunal (PRT) of Phnom Penh. ${ }^{32}$ After initiating the trial against Sary at the ECCC, his co-lawyer challenged the jurisdiction of the ECCC due to the principle of ne bis in idem. Nonetheless, the ECCC Pre-Trial Chamber rejected this argument and asserted, while it in itself had recognized in absentia trials in its legal system, that 'the 1979 trial was not conducted by an impartial and independent tribunal with regard to due process requirements. Consequently, the prosecution, conviction, and sentencing of Ieng Sary in 1979 by the PRT bar neither the jurisdiction of the ECCC over Ieng Sary, nor any of the charges in the Closing Order. ${ }^{33}$ With this statement it seems that the ECCC wanted to make clear that it did not recognize total in absentia trials when there is a problem with the due process rights; it only recognizes in absentia trials, if upon the accused's initial appearance and having been duly summoned to the subsequent hearing, he continues to refuse or fails to attend the proceedings, or is expelled from them, as prescribed in its legal framework.

It is said that in the above cases the principle of 'semel praesens semper praesens,' i.e. to be present at trial once, entails being present forever, is upheld. ${ }^{34}$ In addition, some believe that in these circumstances, the infringement of the duty of the accused to attend trial

Footnote 30 continued

accused be represented by a lawyer and request the Defence Support Section to assign him or her a lawyer, from the lists mentioned at Rule 11.'

${ }^{31}$ See e.g.: Human Rights Watch, Letter to the Secretariat of the Rules and Procedure Committee, 18 November 2006; International Center for Transitional Justice, Comments on Draft Internal Rules for the Extraordinary Chambers in the Courts of Cambodia, November 2006.

${ }^{32}$ Ieng Sary, available at http://www.eccc.gov.kh/en/indicted-person/ieng-sary.

${ }^{33}$ Decision on Ieng Sary's Appeal Against the Closing Order, 11 April 2011, ECCC Pre-Trial Chamber (D427/1/30), para. 175.

${ }^{34}$ Gaeta (n 5 above), 1167. 
must be sanctioned; therefore, the right of the accused to be present at trial is temporarily suspended and the proceedings continue without the defendant. ${ }^{35}$

\subsubsection{The ICC}

According to the legal framework of the permanent ICC total in absentia trials are not recognized before this judicial institution. Article 63(1) of the Rome Statute indicates that 'the accused shall be present during the trial. ${ }^{36}$ This provision is reaffirmed in Article 67(1)(d) of the Rome Statute - concerning the rights of the accused promulgating that the accused has a right 'subject to article 63, paragraph 2, to be present at the trial.' Although trials in the architecture of the Court should be conducted in the presence of the accused, there is nevertheless a quasi-trial that can be held in the absence of the accused, namely the confirmation of charges hearing, that needs to be given attention here.

According to Article 61 of the Rome Statute, the hearing for 'confirmation of the charges before trial' should be held by the PreTrial Chamber 'within a reasonable time after the person's surrender or voluntary appearance before the court. ${ }^{37}$ This mechanism resembles, to some extent, the Rule 61 mechanism at the ICTY and ICTR and is a procedure that, as a compromise, again combines several elements of different legal systems. ${ }^{38}$

In the normal course of events, "the hearing shall be held in the presence of the person charged, as well as his or her counsel. ${ }^{39}$ However, there is a remarkable feature to be found in Article 61 of the Rome Statute, and that is, according to Article 61(2), that the PreTrial Chamber may hold the confirmation hearing in the absence of the person charged upon the request of the Prosecutor or on its own motion. ${ }^{40}$ Such an ex-parte hearing will be justified where the accused

${ }^{35}$ See e.g.: Pons (n 3 above), 1308.

36 The person charged is called 'the accused' or 'the defendant' at trial.

${ }^{37}$ Art. 61(1) Rome Statute.

${ }^{38}$ J. Dong, 'Prosecutorial Discretion at the International Criminal Court: A Comparative Study', (2009) 2 Journal of Politics and Law 109, 110.

${ }^{39}$ Art. 61(1) Rome Statute.

${ }^{40}$ It must be noted that in the case of Ruto's request for excusal, the Prosecutor adduced to Articles 63(2) (the removal of the disruptive accused) and 61(2)(a) (the confirmation hearing in absentia) to prove that they are the only accepted exceptions to the rule of the necessity of the presence of the accused at the courtroom. However, as Chamber V(a) correctly submits in its decision on the case, the idea that a positive 
has waived his right to be present, has fled or cannot be found. The Prosecutor of the Court suggested that the adoption of Article 61(2)(a) helped to resolve disputes about Article 63(1) - which calls for the presence of the accused - by making a compromise, during the drafting stage of the Rome Statute, with those delegations that were in favor of in absentia trials. ${ }^{41}$ According to Rule 124(1) of the RPE: 'If the person concerned is available to the Court but wishes to waive the right to be present at the hearing on confirmation of charges, he or she shall submit a written request to the Pre-Trial Chamber, which may then hold consultations with the Prosecutor and the person concerned, assisted or represented by his or her counsel.' For instance, Katanga waived his right to be present at the confirmation hearing and requested several times to be granted absence from the confirmation hearing. ${ }^{42}$ When the accused waives his right to be present, the Pre-Trial Chamber shall be satisfied that the person seeking the absence from the hearing understands the right to be present and the consequences of his absence. ${ }^{43}$ It falls within the discretionary power of the Chamber to determine whether or not it gives effect to the waiver. Therefore, if the person concerned is available to the Court and the Chamber decides not to hold a hearing in his absence, "it shall order the person to appear. ${ }^{44}$

If the person charged is not available to the Court and is at large, the Chamber has to satisfy itself that all reasonable steps have been taken: i) to secure the person's appearance, ii) to inform him or her of the charges and also of the fact that such a confirmation hearing is to be held in absentia. In this situation, such a deliberate absence with

Footnote 40 continued provision raises a negative implication, namely exclusion of other things not expressly accounted for in the positive provision, expressed in the Latin maxim expression unius est exclusion alterius, is not applicable. In fact, this doctrine is weakend because, as mentioned before, a law is not able to predict everything. Hence, its positive provisions do not imply the exclusion of other possibilities. See:Prosecutor v. Ruto and Sang, (Decision on Mr. Ruto's Request for Excusal from Continuous Presence at Trial) ICC-01/09-01/11 (18 June 2013), paras. 54-63.

${ }^{41}$ Prosecutor v. Ruto and Sang, (Prosecution Appeal Against the Decision on Mr. Ruto's Request for Excusal from Continuous Presence at Trial) ICC-01/09-01/11 (29 July 2013), para. 15.

${ }^{42}$ Prosecutor v. Katanga and Chui, (Mr Katanga's waiver of his right to be present at the Confirmation Hearing pursuant to Rule 124 of the Rules of Procedure and Evidence) ICC-01-04-01/07 (9 July 2008).

${ }^{43}$ Rule 124(2) ICC RPE.

${ }^{44}$ Rule 125(4) ICC RPE. 
knowledge of a coming hearing may be considered as an indication of a waiver of the right to be present. Moreover, the Rome Statute provides for another guarantee in the case of in absentia hearings and that is that 'the person shall be represented by counsel where the PreTrial Chamber determines that it is in the interest of justice. ${ }^{45}$ If the person who has fled, subsequently, is arrested, there is no right to a 'retrial,' but 'the person charged shall be committed to the Trial Chamber established under article 61, paragraph 11.' In this case, 'the person charged may request in writing that the Trial Chamber refer issues to the Pre-Trial Chamber that are necessary for the Chamber's effective and fair functioning. ${ }^{46}$

It is true that the confirmation of charges hearing is not a real trial; only the charges are confirmed at this pre-trial stage and no conviction of the accused can result without his presence. In spite of these considerations, the in absentia confirmation of charges hearing, like the Rule 61 mechanism before the ICTY and ICTR, can be seen as a mechanism which maintains a good balance between different interests at stake in international criminal proceedings before the Court. The existence of such a mechanism entails that the Court does not have to hold total in absentia trials proper, a path followed by the STL, as discussed next.

\subsubsection{The STL}

The STL, that was established controversially, also introduced a controversial mechanism, namely the total in absentia trial. ${ }^{47}$ As Cassese pointed out, the incorporation of this typical feature of the civil law procedure into the STL scheme had been motivated by the influence of the system prevailing in the internal legal system of Lebanon, based on the civil law tradition. ${ }^{48}$ This is exactly what was mentioned by the then UN Secretary-General Kofi Annan, when he noted that 'the constituent instruments of the UN based tribunals had included more common law elements, but [that] the Lebanon tribunal was the first to draw substantially on civil law traditions, and the

\footnotetext{
${ }^{45}$ Art. 61(2) Rome Statute.

${ }^{46}$ Rule 126(3) ICC RPE.

${ }^{47}$ For a critical analysis of the legality of the STL, see: B. Fassbender, 'Reflection on the International Legality of the Special Tribunal for Lebanon', (2007) 5 Journal of International Criminal Justice 1091.

${ }^{48}$ Cassese (n 8 above), 374.
} 
introduction of in absentia trials was the most notable manifestations of civil law elements. ${ }^{49}$ So, the STL, as the most recent established international criminal tribunal, and the IMT at Nuremberg, as the first ever established international criminal tribunal, both explicitly accept(ed) the possibility of conducting in absentia trials. However, unlike the Nuremberg IMT in particular, the STL provides a string of conditions to ensure that such a trial is fair and respects the rights of the accused, in particular by including the accused's right to a retrial. $^{50}$

Article 16(4)(d) of the STL Statute provides that the accused has the guarantee to be tried in his presence. Nonetheless, Article 22 of the STL Statute makes clear that a trial proceeding in the absence of the accused is possible, but 'shall' be conducted under specific conditions. These conditions are met in three situations, namely when the accused: '(a) has expressly and in writing waived his or her right to be present or (b) has not been handed over to the Tribunal by the state authorities concerned or (c) has absconded or otherwise cannot be found and all reasonable steps have been taken to secure his or her appearance before the Tribunal and also to inform him or her of the charges.' The motivation for the provision of trials in absentia in Article 22 was to address the possible refusal by Syria to hand over suspected persons to the Tribunal. ${ }^{51}$ For this purpose, Article 22(b) was considered as a solution to cope with this problem, particularly when there is no legal obligation upon other states to cooperate with the STL to enable the court to try persons of another nationality.

The Secretary-General of the United Nations, Kofi Annan, stated, in his remarks on the establishment of the Lebanon Tribunal, that the inclusion of a provision on trials in absentia could be crucial to ensure that the legal process would not be unduly delayed because of the absence of the accused. ${ }^{52}$ Article 22 has, therefore, adopted a

${ }^{49}$ UN Secretary-General, Report on the Establishment of the Special Tribunal for Lebanon, (S/2006/896), 15 November 2006, para 32.

${ }^{50}$ Gaeta (n 5 above), 1166.

${ }^{51}$ W. Jordash and T. Parker, 'Trials in Absentia at the Special Tribunal for Lebanon', (2010) 8 Journal of International Criminal Justice 507.

${ }^{52}$ UN Secretary-General (n 72 above). The interesting point is that this statement is in contradiction with the previously stated policy of the Secretary-General in his report to the Security Council at the time of the creation of the ICTY, that is 'A trial should not commence until the accused is physically present before the International Tribunal' (Report of the Secretary-General Pursuant to Para. 2 of Security Council Resolution 808, UN Doc. S/25704, 3 May 1993, 101). 
certain terminology, which shows that holding trials in absentia is not merely permitted but is even mandatory. ${ }^{53}$ Rule 105bis(a) of the STL Statute establishes a temporal framework to implement this duty. According to this rule, the Pre-Trial Judge shall ask the Trial Chamber to initiate proceedings, if within a period of 30 calendar days starting from the advertisement referred to in Rule 76bis, the accused is not under the Tribunal's authority. ${ }^{54}$ The indictment against the accused should be advertised to satisfy the requirement set by Article 22(2)(a) of the Statute that asserts: 'When hearings are conducted in the absence of the accused, the Special Tribunal shall ensure that: The accused has been notified, or served with the indictment, or notice has otherwise been given of the indictment through publication in the media or communication to the State of residence or nationality.' There is another obligation imposed upon the STL before starting an in absentia trial; the Court shall ensure that the accused is supported and assisted by counsel, either an appointed counsel or elected one. ${ }^{55}$

It has been stated by many that the use of the in absentia trial by the STL represents a departure from the practice of other international criminal tribunals. ${ }^{56}$ Although some scholars defend the existence of an in absentia trial before the STL and consider it as the reflector of the aim of the drafters to elaborate a more efficient international criminal procedure, ${ }^{57}$ this deviation from the overall

${ }^{53}$ Jordash and Parker (n 51 above), 495.

${ }^{54}$ Rule 76bis: 'In keeping with the President's order made under Rule 76(E), a form of advertisement shall be transmitted by the Registrar to the authorities of any relevant State or entity for publication in newspapers and/or for broadcast via radio, television and/or other media, including the internet, providing notification to the public of the existence of an indictment and calling upon the accused to surrender to the Tribunal or in any case to submit to its jurisdiction. The advertisement shall invite any person with information as to the whereabouts of the accused to communicate that information to the Tribunal.'

${ }^{55}$ According to Article 22(2), the Tribunal shall ensure that: 'The accused has designated a defense counsel of his or her own choosing, to be remunerated either by the accused or, if the accused is proved to be indigent, by the Tribunal;(c) Whenever the accused refuses or fails to appoint a defense counsel, such counsel has been assigned by the Defense Office of the Tribunal with a view to ensuring full representation of the interests and rights of the accused.'

${ }^{56}$ E.g. R. Riachy, 'Trial in Absentia in the Lebanese Judicial System and at the Special Tribunal for Lebanon: Challenge or Evolution?', (2010) 8 Journal of International Criminal Justice 1305.

${ }^{57}$ E.g. C. Aptel, 'Some Innovations in the Statute of the Special Tribunal for Lebanon', (2007) 5 Journal of International Criminal Justice 1123. See also generally: 
practice has also provoked heavy and widespread criticism. For instance, Jalloh has explicitly held that the STL provision is a violation of human rights norms. ${ }^{58}$ It seems that such constant criticism caused Schabas to mention that in absentia proceedings at the STL would not be exercised in practice, in the same way that the prosecution of persons aged 15 at the SCSL have never been materialized due to its controversial nature, though it was accepted by the legal framework of the SCSL. ${ }^{59}$ Nonetheless, this prediction did not hold true.

On 1 February 2012, the Trial Chamber of the STL, in accordance with Rule 106, decided to try four accused in absentia, namely Sallim Ayyash, Mustafa Badreddin, Hussein Onneisi and Asad Sadra. ${ }^{60}$ The Trial Chamber came to this decision while it acknowledged that 'a trial in an accused's presence is preferable, even in the particular circumstances of this case, and agrees with the President's statement in his Rule 76 Order that it is in the best interests not only of the accused, but also of the Tribunal - with its purpose of achieving a fair and efficient trial to establish truth and promote reconciliation within Lebanon - for each accused to be present and to fully participate in his own defence. ${ }^{61}$ Yet, the Chamber did not consider the legitimacy of an in absentia trial and exclusively assessed the legal and statutory requirements of conducting an in absentia trial, i.e. 'the first is that the Trial Chamber must be satisfied that an accused has absconded or cannot be found. The second is that all reasonable steps have been taken to secure the appearance of the accused before the Tribunal. The third, concurrent with the second, is that all reasonable steps have been taken to inform the accused of the charges in the indictment. ${ }^{62}$ Finally, since the Trial Chamber stated in its decision that 'a trial in absentia obviously cannot await the arrest of an accused, as this would defeat the rationale of the Tribunal's Statute and Rules. ${ }^{, 63}$

Footnote 57 continued

C. Ryngaert, Jurisdiction in International Criminal Law (Oxford: Oxford University Press, 2008), 119-125.

${ }^{58}$ C. Chernor Jalloh, 'Self-representation and the Use of Assigned, Standby and Amicus Counsel' in L. Carter and F. Pocar, (eds.), International Criminal Procedure: The Interface of Civil Law and Common Law Legal System (London: Edward Elgar Publishing Limited, 2013), 155.

${ }^{59}$ Schabas (n 12 above), 378 .

${ }^{60}$ Decision to Hold Trial In Absentia (n 19 above), 47.

${ }^{61}$ Ibid., para. 20.

${ }^{62}$ Ibid., para. 27.

${ }^{63}$ Ibid., para. 41. 
Then, on 16 January 2014, the in absentia trial at the STL started, dealing with the Ayyash et al. case.

\subsection{Appraisal of Total In Absentia Trials}

As mentioned earlier, total in absentia trials were explicitly allowed before the IMT in Nuremberg and are nowadays accepted before the STL. No other international criminal tribunals have allowed this possibility. Only when the accused initially appeared in court and subsequently fled, refused or was otherwise unavailable, some international criminal tribunals have allowed the proceedings to go ahead without the presence of the accused in the courtroom.

We now turn to the question whether total in absentia trials can objectively be considered legitimate. This can be assessed from two distinct perspectives: the practical and theoretical perspective. The former perspective considers the practical consequences of an action and its desirability and underlying values; the latter perspective focuses mostly on whether the process is consistent with some relevant objective norms and beliefs. ${ }^{64}$

\subsubsection{The Practical Perspective}

As mentioned before, a total in absentia trial refers to a situation in which the judicial system lacks control of the accused, because the accused is at large. This situation does not include a case where the accused is absent, because he has waived his right to be present, while a court still has the power to force him to be present. Pragmatism focuses on the practical consequences of a conduct or mechanism to assess if such a mechanism is right or wrong. ${ }^{65}$ From this rather pragmatic perspective, in the context of international criminal proceedings, a total in absentia trial is not useful and does not have significant practical results. The overriding goal that underlies criminal proceedings is punishing the defendant for wrongful conduct. ${ }^{66}$

\footnotetext{
${ }^{64}$ For more information about practical versus theoretical reasons see: entry of Standford Encyclopedia at (http://plato.stanford.edu/entries/practical-reason/). These two distinct perspectives are - to a large extent - similar to the so-called deontological and teleological perspectives, respectively.

${ }^{65}$ See e.g.: Entry of Pragmatism in Stanford Encyclopedia of Philosophy (http://plato.stanford.edu/entries/pragmatism/\#PraPra).

${ }^{66}$ See e.g.: J. D. Ohlin, 'Goals of International Criminal Justice and International Criminal Procedure', in: G. Sluiter, H. Friman, S. Linton, S. Vasiliev and S. Zappala, International Criminal Procedure: Principles and Rules (Oxford: Oxford University Press, 2013), pp. 55-68.
} 
However, this is not to say that the content of the punishment whether it is deterrence or retribution for instance - is not important. Punishment is a subject-oriented notion and should be imposed upon a person. When the convicted person is not present to undergo the punishment, the question may be raised what the usefulness of a conviction entails. As the law should in principle be administrated, it can be held that a conviction without administration is on its face valueless.

The legitimacy of an in absentia trial as adopted by the STL can also be assessed here. From a practical perspective, such a trial is valueless as the existence of in absentia trials at the STL is subject to another measure to protect the rights of the accused, namely the right to 'retrial.' Article 22(3) of the STL Statute states that 'in case of conviction in absentia, the accused, if he or she had not designated a defense counsel of his or her choosing, shall have the right to be retried in his or her presence before the Special Tribunal, unless he or she accepts the judgment.' A sentence without possibility to be enforced may be seen by the public as a weak feature of the STL and this will not be beneficial to the legacy of the STL. ${ }^{67}$ Justice to victims, on the other hand, may be considered to be a valid reason to justify total in absentia trials, as justice to victims can be considered as one of the goals of international criminal justice also. ${ }^{68}$ However, in the absence of any (empirical) research on this with regard to the STL, being the only modern international criminal tribunal allowing total in absentia trials, it is unclear whether victims of international crimes themselves believe that the in absentia trial at the STL is beneficial to them. ${ }^{69}$ As mentioned before, all advantages, including

${ }^{67}$ Klerks (n 10 above), 68.

${ }^{68}$ See e.g.: A-M de Brouwer and M. Heikkilä, 'Victim Issues: Participation, Protection, Reparation, and Assistance', in: G. Sluiter, H. Friman, S. Linton, S. Vasiliev and S. Zappala, International Criminal Procedure: Principles and Rules (Oxford: Oxford University Press, 2013), 1368-1370.

${ }^{69}$ For some discussion on this point, see: M. Gardner, 'Reconsidering Trials In Absentia at the Special Tribunal for Lebanon: An Application of the Tribunal's Early Jurisprudence', (2011) 43 George Washington International Law Review 134 (where mention is made that international criminal trials in absentia could lead to a loss of credibility for the court and disappointment for the victims), 135 ('Thus trials in absentia can provide at least partial justice from a societal perspective, even if they fall short of full vindication and closure for victims'). See also for those in favour of in absentia trials as it may offer justice to victims: Al-Monitor, Special Tribunal Moves Toward Trial In Absentia, 18 December 2012 (Sir David Baragwanath (President of the STL): 'The problem with not having trial in absentia is that if an accused manages to hide, the community do not have the facts of the case presented 
those for victims that are imaginable for an in absentia trial can possibly be better realized by some pre-trial mechanisms such as Rule 61 at the ICTY or the Article 61 confirmation of charges hearing at the ICC. It does not necessarily need to hold a full trial.

The pointlessness of having in absentia trials has another reason. According to human rights norms, an in absentia trial should be accompanied with the possibility of a 'retrial' for the mechanism to be considered fair. This means that the accused has the right to appear in court at any moment and request that proceedings be commenced again, even if he has already been convicted in absentia. ${ }^{70}$ So, from the perspective of judicial economy, conducting a trial in the absence of the accused that is subject to 'retrial' is not economical and reasonable and can be seen as a waste of time and money. The administration of justice in the international sphere considerably increases the costs. The STL is a good example here. The approved budget for this tribunal for each year amounts to nearly $60,000,000$ Euros and to date, the tribunal has cost an estimated 500,000,000 US Dollars in total. ${ }^{71}$ Conducting an in absentia trial that is subject to retrial is thus an expensive way to seek justice. Upon the presence of the accused, a retrial can highly increase the costs. So, from a rational perspective, the in absentia trial is not easily justified, simply because its cost prevail its benefits. Maybe due to these facts, the STL itself explicitly admitted that 'there is one aspect of these proceedings that should not

Footnote 69 continued

formally before the court and contested by the defence counsel in the way that can happen with a trial in absentia. And that can mean, particularly for victims, that what they have experienced; the agony of either personal injury or loss of a loved one, does not encounter the court analysis that the trial does. And since trial in absentia permits that, it serves the interest of the victims and the members of the community where the events have taken place. There is of course an expense but that's a cost that has been accepted as payable under our statute.'; C. K. Benedik, 'Trials in Absentia, International Criminal Law, and the Modern Human Rights Regime: Furthering or Hindering Victims and Societies?', available at: http://www. academia.edu/8349773/Trials_in_Absentia_International_Criminal_Law_and_ the_Modern_Human_Rights_Regime_Furthering_or_Hindering_Victims_and_ Societies.

${ }^{70}$ The European Court of Human Rights rules in para. 87 of its Judgment of 13 February 2012 in the case of Krombach v. France, No: 29731/96, that: 'the authorities have a positive obligation to afford the accused the opportunity to have a complete rehearing of the case in her or her presence.'

${ }^{71}$ See: Special Tribunal for Lebanon, Sixth Annual Report (2014-2015), p. 27; A. Taylor, 'The U.N.'s tribunal in Lebanon has cost millions and made no arrests. Now the journalists are on trial, The Washington Post, 7 April 2015. 
be forgotten: a trial in absentia is only the second best option in the circumstances. ${ }^{72}$

However, the prohibition of total in absentia trials does not hamper justice. When the accused flees, it does not put an end to the proceedings against him. The court can take some measures to protect other interest; for instance the assets of the accused can be seized; the victims can be heard in a quasi-trial hearing, like the confirmation of charges hearing before the ICC or the Rule 61 mechanism in the ICTY/ICTR; or an arrest warrant or a travel ban can be imposed upon the accused to limit his movement. Indeed, a distinction should be drawn between the investigative stage and trial phase. An investigation could be initiated in the absence of a suspect. As the Supreme Court of Appeal of South Africa held in its decision of November 2012, there is no reason why an investigation should not be initiated, provided there is a prospect of a perpetrator's presence. ${ }^{73}$ By such a distinction, a balance can be maintained between all parties to a criminal case. The voice of the victims could be heard through the commencement of an investigation and the public is also informed that justice is being done; therefore, the reputation of the judicial system can be preserved. Nonetheless, it is not reasonable to authorize a court to bring a case to an end and convict the accused when he is not under the court's control.

In contrast with the approach that is adopted by some internationalized tribunals (see section 2.1.3), it must be said that if the accused upon his initial appearance flees, it does not change the circumstances to justify an in absentia trial. Fleeing is a crime independently, but it must not be punished by prescribing an in absentia trial. It could be sanctioned by an extra punishment when the accused is arrested. The integrity and coherency of the criminal proceedings should be preserved and defended. A total in absentia trial is not a proper alternative to the arrest warrant mechanism. The implementation of an arrest warrant is a bridge between the pre-trial phase and trial stage. Until the accused is at large, the pre-trial phase shall continue. Indeed, there is another argument in favor of the prohibition of total in absentia trials. It is the responsibility of a court to make the accused present and, for this reason, criminal courts are inherently empowered with the power of issuance of an arrest war-

\footnotetext{
${ }^{72}$ Special Tribunal for Lebanon, Sixth Annual Report (2014-2015), 35.

73 The Supreme Court of Appeal of South Africa, Judgment in the Matter between National Commissioner of the South Africa Police Service v. Southern African Human Rights Litigation Centre (485/2012) ZaSCa 168, 27 November 2012, para. 66.
} 
rant. If a court is authorized to conduct total in absentia trials, it covers the problem of the weakness of the court to capture the accused. Courts should be banned from carrying out an in absentia trial in order to make serious attempts to arrest the accused. In other words, it must not be ignored, as pointed out by Paulussen with respect to the ICC, that introducing in absentia trials will run the risk of masking the real problem, that is that the enforcement arms of the ICC, formed by States Parties to the Rome Statute, is not functioning as it should be. ${ }^{74}$

\subsubsection{The Theoretical Perspective}

Apart from the practical assessments, the question whether the international criminal justice system should be empowered with an authority to try the accused in his absence could be answered within a normative framework that is applicable to this system.

2.2.2.1 Consistency with International Human Rights Law. International criminal law grew out of the human rights movement. ${ }^{75}$ The emergence of human rights was of a revolutionary effect and constituted a paradigm within which the human thoughts have been formed. Human rights standards are a normative framework within which the legitimacy and thus the possibility of all actions performed by the international tribunals can be measured against, including the holding of an in absentia trial. This normative framework could be called the 'consistency test.' For instance, The Rome Statute asserts that the application and interpretation of the law must be consistent with internationally recognized human rights. ${ }^{76}$ This implies that the Court does not recognize whatever is inconsistent with human rights norms and standards. This test governs the whole functioning of the Court. Whenever the ICC exercises its jurisdiction or it is involved in a case, that involvement and exercise of jurisdiction have to be applied and interpreted in conformity with those internationally recognized human rights' relevant to the ICC's functioning, including the proceedings in the court room and during the pre-trial phase. ${ }^{77}$ However, this ruling test does not only apply to the ICC, but to all other international tribunals,

\footnotetext{
${ }^{74}$ Paulussen, (n 20 above), 1050.

${ }^{75}$ M. M. DeGuzman, 'How Serious Are International Crimes? The Gravity Problem in International Criminal Law', (2012) 51(18) Columbian Journal of Transitional Law 51.

${ }^{76}$ Article 21(1)(c) Rome Statute.

${ }^{77}$ Paulussen (n 20 above), 1033.
} 
including the STL. Therefore, the possibility of holding an in absentia trial must be assessed by the human rights standards.

There is no doubt that the legitimacy of the international criminal tribunals comes from the manifested fairness of their procedures and punishments. ${ }^{78}$ For this purpose, one must lay down an important normative framework that protects the rights of the accused, namely 'the right to a fair trial.' The fair trial principle is not a single right, but embraces a wide range of standards such as the right to a fair hearing, the right to an effective defense and the "principle of equality of arms' in criminal proceedings. Generally speaking, the right to a 'fair trial' guarantees the right of an accused to participate effectively in a criminal trial. ${ }^{79}$ It is the principle of a 'fair trial' that functions as the foundation of international criminal procedure, which provides coherency and legitimacy to it as a body of international law. ${ }^{80}$ The importance of a fair trial is insisted by all tribunals. For instance, Article 16(2) of the STL Statute states that 'the accused shall be entitled to a fair and public hearing.' Cassesse considered the principle of a fair trial as a universally accepted principle of international law that, by now, has belonged to the category of customary norms. ${ }^{81}$ In addition, the importance of the principle of a fair trial can be understood by the statement expressed by Chief Prosecutor Jackson of the Nuremberg IMT who said that history would assess the proceedings in light of the fairness with which the defendants were treated. ${ }^{82}$ It is argued that the international tribunals and courts, including the ICC, should be more concerned with the appearance of fairness, because they do have to establish their legitimacy. ${ }^{83}$

${ }^{78}$ D. Luban, 'Fairness to Rightness: Jurisdiction, Legality, and the Legitimacy of International Criminal Law', in: S Besson and J. Tasioulas, (eds.), The Philosophy of International Law (Oxford University Press, Oxford, 2010), 579.

${ }^{79}$ M. Fedorova, The Principle of Equality of Arms in International Criminal Proceedings (Antwerp-Oxford: Intersentia, 2012), 437.

${ }^{80}$ G. Boas et al., International Criminal Procedure (New York: Cambridge University Press, 2010), 4.

${ }^{81}$ Cassese (n 8 above), 384. This point of view has been acknowledged by the Court; see e.g.Prosecutor v. Lubanga, (Separate Opinion of Judge Georghios M. Pikis, Decision on the Prosecutors' Application for Leave to Reply) ICC-01/04-01/ 06-424 (12 September 2006), para. 3: 'The right to a fair trial has been proclaimed as a legal norm and its incorporation in international instruments denotes comprehensive assent to its emergence as a principle of customary international law.'

${ }^{82}$ Schabas (n 17 above), 219.

${ }^{83}$ Jalloh (n 58 above), 155. 
The right to a fair trial aims at enabling the accused to defend himself effectively. The right to an effective defense is the cornerstone of a fair trial. The presence of the accused at trial is desirable because it is of great benefit for the accused to defend himself effectively.

Regarding the established normative framework, namely the right to defend effectively, which requires the presence of the accused at trial, one can readdress the conceptual question about the meaning of an in absentia trial. The term 'in absentia trial' means a trial in which the accused is not able to defend himself effectively. Therefore, the requirement of the accused's presence at trial implies more than his mere physical presence in the courtroom. ${ }^{84}$ Indeed, what should be available is the existence of the possibility in which the accused can defend himself effectively. For this reason, an ICTY Trial Chamber in the Strugar case asserted that the prohibition of an in absentia trial 'would appear to be void of any substance if it related to the mere physical presence of the accused in court. ${ }^{, 85}$ There are two situations, in which the mere physical presence of the accused does not meet the requirement of a fair trial. It also shows that the ultimate purpose of the right to be present at trial is enabling the accused to defend himself effectively. Firstly, when the accused is not in a position to understand the proceedings due to a lack of knowledge of the official language of the court he will not be able to defend himself. Therefore, he will be entitled to have a translator. If the accused is not able to defend effectively, his right is violated, even though his presence is provided. Indeed, an 'effective presence' of the accused is required. For this reason, according to the Rule 10(c) of the RPE of the STL, the accused has a right to use his own language and also, in accordance with Rule 65(a)(iii), receive assistance of an interpreter. Secondly, when the accused suffers from an illness that impairs his ability to attend trial, the hearing cannot proceed. Rule 135(4) of the Rules of Procedure and Evidence of the ICC direct the Trial Chamber to adjourn the proceedings when it is satisfied that the accused is unfit to stand trial. Although there is no provision specifically addressing the fitness to stand trial in the ICC legal framework, Pre-Trial Chamber I submitted in its decision on the fitness of Mr. Gbagbo (Republic of Cote d'Ivoire situation), this concept 'must be viewed as an aspect of the broader notion of fair trial' and it is an obligation upon the Chamber to 'ensure, as spelled

\footnotetext{
${ }^{84}$ Schabas (n 17 above), 306.

${ }^{85}$ Prosecutor v. Strugar, (Decision of the Defence Motion to Terminate Proceedings) IT-01-42-T (26 May 2004), para. 32.
} 
out in rule 135 of the Rules, that proceedings did not take place against an unfit suspect. ${ }^{86}$ The exemption for an ill accused to attend trial is not because of his illness as such, but because it has bad effects on his effective defense.

2.2.2.2 Common vs. Civil Law Systems. The meaning of the right to be heard can be understood in the context of two distinct legal traditions, namely the 'common' and 'civil' law systems. It must be noted that Cassese mentioned that neither model can ever be found in its pure form anywhere and they must be studied as the 'ideal type' propounded by Max Weber. ${ }^{87}$ It is widely accepted, as mentioned earlier, that the prohibition of the in absentia trial is a feature of the 'adversarial/accusatorial ${ }^{88}$ system as a legal tradition of the common law regimes. ${ }^{89}$ From the perspective of the common law system, a trial resembles a 'duel' between two parties at the trial, namely the Prosecutor and the defendant. Therefore it requires the presence of both sides to a proceeding. The logic behind this provision is clear: as the trial consists of a contest between two parties, no trial properly may start if one of them is missing. ${ }^{90}$ Therefore, everyone charged with a criminal offence has a right to be tried in their presence so that they can hear and challenge the Prosecutor's case and present a defense that must be heard. This requirement is reflected in the concept of 'audi alteram partem' (literally meaning 'hear the other side') as a rule of natural justice. ${ }^{91}$

In this context, the principle of 'equality of arms' emerges. This principle is aimed at strengthening an effective defense. An effective defense must be set as a standard which determines other rights of the accused to guarantee a fair trial, including the right to 'self-repre-

${ }^{86}$ Prosecutor v. Gbagbo, (Decision on the fitness of Laurent Gbagbo to take part in the proceedings before this Court) ICC-01/11-01/11(2 November 2012), paras. 43 and 56.

${ }^{87}$ Cassese (n 8 above), 353.

${ }^{88}$ The adversarial element focuses on the responsibility of parties for developing the legal and factual issues, while the accusatorial element allocates burdens between parties with respect to the adjudication of guilt. See Cassese (n 8 above), 351.

${ }^{89}$ Schabas states that the fact that common law jurisdiction make a number of exceptions, and allow for trial in absentia where appropriate, shows that this is not an issue of fundamental values so much as one of different practice. See Schabas (n 17 above), 305 .

${ }^{90}$ Cassese (n 8 above), 370.

${ }^{91}$ Legal Digest of an International Fair Trial (Poland: the OSCE Office for Democratic Institutions and Human Rights (ODIHR), 2012), 133. 
sentation,' the right to be represented by counsel of one choice, ${ }^{92}$ and the right to receive free legal assistance when the accused cannot afford the cost of legal aid. These rights keep a fair balance between the 'accuser' and 'accused' which is sought by the principle of equality of arms. This principle implies that the accused may not be put at a serious procedural disadvantage with respect to the Prosecutor. ${ }^{93}$ In fact, the prohibition of hearings in absentia, where only the Prosecutor, but not the defendant, is present is a requirement of procedural equality. Therefore, according to the principle of equality of arms, if the Prosecutor is present and the accused is absent, there is a violation of 'equality of arms. 94

On the contrary, the 'civil law approach' tolerates an in absentia trial to a greater extent. For these jurisdictions there are two arguments in favor of the in absentia trial. At first, it has been held that in the context of the civil law systems the interest of justice may prevail over the interests of the accused. ${ }^{95}$ Indeed, all crimes concern and impact on the public order. The prosecution also represents society (including the victims) in order to work towards establishing the truth and justice; it follows that the defendant's absence from the trial cannot of itself halt the course of justice. ${ }^{96}$ However, it does not seem a totally cogent argument. Justice is done when all interests including the interest of the accused, are preserved.

The second argument is related to the issue of the truth. The common law tradition considers the criminal proceedings as a forum whereby the truth needs to be found and established. In the context of this system, it is primarily the responsibility of the judges to find the truth. ${ }^{97}$ Due to the objectivity feature of the truth, the judge can ascertain the facts even without the presence of the accused. Indeed, the main distinction between the civil and common law tradition lays down in their different approaches to the notion of truth and the way in which they define the truth. The common law approach adopts a more 'subjective approach' to the truth. The truth is not objective but it is a contextual and phenomenon concept, like what the contrac-

\footnotetext{
${ }^{92}$ Art.14(3)(d) ICCPR.

${ }^{93}$ Cassese (n 8 above), 384.

${ }^{94}$ Fedorova (n 79 above), 52.

${ }^{95}$ See e.g.: B. McGonigle Leyh, Procedural Justice?: Victim Participation in International Criminal Proceedings (Antwerp: Intersentia, 2011), 34-35.

${ }^{96}$ Riachy (n 79 above) 1297.

${ }^{97}$ Ambos and Bock (n 21 above), 490.
} 
tualists believe with respect to the moral values. ${ }^{98}$ This understanding of the notion of truth requires that the accused be heard because part of the truth is in his hands and adopting a pluralist approach to the truth is therefore necessary. It is such a distinction that was described by former Judge Röling of the Tokyo IMT as 'real truth' and the 'trial truth. ${ }^{99}$ On the contrary, the civil law tradition defines the truth as an absolute and objective concept. Therefore, the presence of the accused is not necessary, though it is desirable. Indeed, the judge is able to find the truth on his own and he will manage, because he is a professional person.

Nonetheless, it seems that the civil law approach to the truth is not all precise. Although the truth is objective, it is not one-sided. On the contrary, the truth is a plural notion and finding the truth requires adopting a plural approach. The truth resembles a shattered mirror; each part of this unique mirror belongs to someone. These separate parts should be attached together to find and form the truth. Indeed, you will find parts of the truth everywhere and the whole truth nowhere. ${ }^{100}$ In the context of criminal proceedings, one part of the truth comes from the accused. He should therefore be heard. The perspective of the accused cannot be replaced by the judge's take on the events.

2.2.2.3 Waiver of Right to be Present at Trial. The fair trial principle requires the presence of the accused at trial. The presence at trial as a right has two implications; firstly, conducting an in absentia trial is prohibited because it is a violation of the accused's right. Secondly, the accused may waive his right to be present at trial.

Waiving of the right to be present at trial can be done either explicitly or implicitly. Both kinds of waiver must be free and unequivocal and should be done with full knowledge. ${ }^{101}$ There are some situations that can be considered as an implied waiver of the right to be present at trial. Disappearance after the first appearance is one of them. The doctrine of 'semel preasens simper praesens' (to be present

\footnotetext{
98 See: The Search for Truth in Criminal Process, (http://www.cesl.edu.cn/ upload/201209206168631.pdf).

${ }^{99}$ B.V.A. Röling and A. Cassese, The Tokyo Trial and Beyond: Reflection of a Peacemonger (Cambridge: Polity, 1992).

${ }^{100}$ To study the idea of truth as the shattered mirror, see: A. Appiah, Cosmopolitinism: Ethics in a World of Strangers (Issues of Our Time) (New York: Norton \& Company, 2006),13-33.

${ }^{101}$ Boas et al. (n 80 above), 237.
} 
once is to be present always) that is applied by a number of jurisdictions ${ }^{102}$ allows trials to continue in case the accused disappears during the proceedings. ${ }^{103}$ Here, fleeing could be considered as a behavior that shows the deliberate waiving of the right to be present at trial. As mentioned before, some internationalized courts accept such interpretation of fleeing. However, it seems that in the case in which the accused is at large and the issued arrest warrant against him is still pending, adopting such a perception is not accepted. Nobody can claim that an at large suspect will not intend to defend himself when he is later arrested. Fleeing does not necessarily imply that the accused does not intend to defend. As mentioned earlier, the right to be present at trial refers to the right to defend effectively, not a mere physical presence at the courtroom. The accused may have escaped from the courtroom due to a wide range of reasons, but if he is arrested he will probably defend himself. Anyway, even where one can characterize such a trial, in which the absconding accused has not explicitly waived his right to be present, as a fair one, it is still valueless and should be avoided.

With respect to the STL, the status of an in absentia trial before the STL is not simple. The Statute of the Tribunal includes some different situations. One situation is compatible with the established human rights standards, where the accused waives his right to be present at trial. The waiver of right to be present at proceedings before the Tribunal can be made expressly or implicitly, but it must be proved. Therefore, Rule 106 of the STL Statute provides that the tribunal must ensure that all reasonable steps have been taken to inform the accused and the requirements of Article 22(2) have been met. On the contrary, other situations, i.e. when the accused has not been handed over to the Tribunal or has not been found, violate the right to a fair trial. These hypothetical situations embrace a scenario, where the accused wants to be present but is not able due to external limits like being detained at a State. Pons called this scenario the 'detention scenario abroad' and asserts that it is the only situation in which it is extremely difficult to find a convincing lawful basis for an in absentia trial to be held. ${ }^{104}$ With respect to fleeing, as mentioned before, the knowledge of an absconding accused of the charges

\footnotetext{
102 See, for instance, Article 488 of the Italian Criminal Procedure Code.

103 Jordash and Parker (n 51 above), 494.

${ }^{104}$ Pons (n 3 above), 1312.
} 
against him should not lead to this conclusion that he has waived his right to defend himself. It is asserted that in case of the accused at large, a lower threshold may be accepted to determine the 'actual knowledge' that is required to respect the right to notification to be respected. ${ }^{105}$ Yet such knowledge does not necessarily correspond with the waiver of the right to be present. On the contrary, to determine the accused's waiver requires a high evidentiary threshold.

Courts should try to establish their legitimacy by conducting a fair trial. It is not accepted to replace the failure of the courts to prove their fairness with in absentia trial. It must be borne in mind that the process whereby alleged perpetrators of serious crimes are brought to justice will have a real impact on ending impunity for these crimes. If the process is viewed as unfair, this perception will create an additional obstacle to a society transitioning to one characterized by the rule of law and respect for human rights. ${ }^{106}$

\section{PARTIAL IN ABSENTIA TRIALS}

Over time the strict approach to in absentia trial has been modified; the prohibition of conducting an in absentia trial has remained as a principle, but with some few exceptions. These exceptions are discussed in the current section and go under the name of partial in absentia trial. These exceptions are in consistency with the fair trial principle, because they include the situations in which the accused's waiver of the right to be present is implied. Although the consent of the accused remains as the key element in order to assess the legitimacy of the absence of the accused, a marginal interpretation has emerged to define some behaviors as the implied consent of the accused not to be present. Indeed, the notion of the fairness has been a dynamic notion. Mainly, the fairness of proceedings is defined very strictly and in a one-sided manner; a trial is considered fair if during the trial all rights of the accused, and only his rights, are respected. This viewpoint strongly objects that the fair trial notion goes beyond the accused's rights. Zappalà asserts that it is not a broad 'one size fits

105 Ibid., 1315.

${ }^{106}$ Human Rights Watch, 'Letter to the Secretariat of the Rules and Procedure Committee Extraordinary Chambers of the Courts of Cambodia', 8, available at: http://www.hrw.org/sites/default/files/related_material/Letter\%20Cambodia-HRW ECCC\%20Rules\%2011.17.06_0.pdf. 
all' notion. ${ }^{107}$ Nonetheless, the understanding of the notion of fairness has changed and its scope has broadened over time. This change is a product of the international tribunals attitude. Many of these tribunals have recognized that fairness is principally but not solely owed to the accused and other actors may be regarded as holder of such rights. ${ }^{108}$ The broad notion of 'interest of justice' is an interchangeable concept that is widely used by the ICC to refer to multiple aspects of fairness. Now, one can asserts that fairness and justice is not only an accused-oriented notion, but it is a status in which all interests of different parties to a criminal proceeding are respected. A trial is considered fair and just if there is a reasonable balance between all interests attendant at trial. This change in the understanding of the notion of fairness has some practical consequences with respect to the legitimacy of in absentia trial; it extends the scope of permitted partial in absentia trials. The presence of the accused at trial is a right, but the right holder is able to waive such a right. Due to the interest of other parties to the criminal proceedings, a liberal approach has been adopted to determine the waiver of a right.

A number of situations in which the accused waives his right to be present at trial, explicitly or implicitly, is discussed next. These include: (1) the accused's disruptive behavior in court; and (2) the accused's voluntary absence in court.

\subsection{Disruptive Behavior}

A first scenario that implies a waiver of the right to be present at trial is the disruptive behavior of the accused in the courtroom, which may lead to his removal from the courtroom. The Appeals Chamber of the ICC has mentioned in one of its decisions that the continuously disruptive behavior of the accused may be construed as an implicit waiver of his or her right to be present. ${ }^{, 09}$ It is widely believed that if the accused continues to intentionally disrupt the proceedings while

${ }^{107}$ S. Zappalà, 'The Rights of the Victims v. The Rights of the Accused', (2010) 8 Journal of International Criminal Justice 137, 149. Also, see: Y. McDermott, 'Rights in Reverse: A Critical Analysis of Fair Trial Rights under International Criminal Law', in: W. Schabas, Y. McDermott, and N. Hayes (eds.), The Ashgate Research Companion to International Criminal Law (London: Ashgate, 2013).

${ }^{108}$ Friman, Linton et al. (n 68 above), 805.

109 Prosecutor v. Ruto and Sang, (Judgment on the appeal of the Prosecutor against the decision of Trial Chamber V(a) of 18 June 2013 entitled 'Decision on $\mathrm{Mr}$ Ruto's Request for Excusal from Continuous Presence at Trial) ICC-01/09-01/11 OA5 (25 October 2013), para. 51. 
he is aware of the consequences of his deed, namely removal from the trial, it implies that he waives his right to be present at trial. The situation defined in Article 63(2) of the Rome Statute refers to such an instance, namely removing the accused from the courtroom by the Judge because of the accused's disruption of the trial. According to this provision, 'if the accused, being present before the Court, continues to disrupt the trial, the Trial Chamber may remove the accused and shall make provision for him or her to observe the trial and instruct counsel from outside the courtroom, through the use of communications technology, if required. Such measures shall be taken only in exceptional circumstances after other reasonable alternatives have proved inadequate, and only for such duration as is strictly required.' Indeed, the presence of the accused is the main principle and the exclusion from the hearings is an exception. Such an exception should not become the principle and should not be misused by the Court. As Schabas asserted, the definition of disruption should not become a tool to muzzle defendants in circumstances where they challenge the charges. ${ }^{110}$ That is why removing the accused must be used as a last resort. Article 63 of the Rome Statute promulgates that the accused must continue to disrupt the trial. It means that the trouble made by the accused must be repetitive and persistent. ${ }^{111}$ This condition and threshold must be satisfied to ensure that the behavior of the accused implies his intention to waive his right to be present at trial. From another perspective, it can be said that the disruptive defendant is abusing the right to be present at the courtroom. ${ }^{12}$ It is accepted that the abuse of a right can lead to the suspension of a right. Pre-Trial Chamber V(a) of the Court submitted in the Ruto case that 'the primary purpose of Article 63(2) is to grant to the Trial Chamber the power to prevent the accused form exercising what is also a right, when the accused insists on exercising that right in a disruptive way. 113

It should be borne in mind that the above-mentioned situation that justifies a partial in absentia trial is exclusively related to these cases where the accused is under the control of the court. It does not include situations in which the accused has not been arrested yet and

${ }^{110}$ W. A. Schabas, International Criminal Court: A Commentary on the Rome Statute (New York, Oxford University Press, 2010), 755.

${ }^{111}$ Schabas (n 7 above), 307.

112 Jordash and Parker (n 51 above), 490.

113 Decision on Mr Ruto's Request for Excusal from Continuous Presence at Trial (n 40 above), para. 59. 
is at large. There is a strong obligation upon judicial organizations to arrest and apprehend the person charged in order to prosecute him. Such organizations are not allowed to evade this responsibility by conducting an in absentia trial and replacing an imposed counsel on the accused. If a court is allowed to carry out an in absentia trial, there is no need any more of police forces and certain coercive measure to bring suspects to justice.

\subsection{Voluntary Absence}

When the accused waives his right to be present at the courtroom it means that there is no ban on holding an in absentia trial anymore, since such right is not a non-derogable right, but a waivable one. The UN Human Rights Committee (HRC) pointed out in the Mbenge $v$. Zaire Communication, regarding Article 14 (3)(d) of the ICCPR: 'Indeed, proceedings in absentia are in some circumstances (for instance, when the accused person, although informed of the proceedings sufficiently in advance, declines to exercise his right to be present) permissible in the interest of the proper administration of justice. ${ }^{114}$

To determine whether the accused has waived his right to be present at trial it must be determined that he has done it deliberately and on the basis of actual knowledge of the consequences of his waiver, namely the continuation of the proceedings without his presence. A court may not commence or proceed with a trial in the accused's absence, unless the Prosecutor, who is responsible for the burden of proving the accused's knowledge, is able to establish that the accused possessed the actual knowledge and clearly intended to waive his right to be present. ${ }^{115}$ The ECHR, in the case of Somogy $v$. Italy, stated: 'Article 6 of the Convention imposes on every national court an obligation to check whether the defendant has had the opportunity to appraise himself of the proceedings against him. ${ }^{116} \mathrm{It}$ implies that there is an evidentiary presumption in favor of the nonexistence of the accused's intention to waive his right. Therefore, it is the Prosecutor's responsibility to prove the accused's awareness of and intention to waive his right to be present. As mentioned above,

${ }^{114}$ Daniel Monguya Mbenge v. Zaire, Communication No. 16/1977, U.N. Doc. Supp. No. 40 (A/38/40) at 134 (1983).

115 Jordash and Parker (n 51 above), 493.

116 Judgment in case of Somogyi v. Italy, 18 May 2004, European Court of Human Rights (No. 67972/01), para 72. 
the case of Gbao before the SCSL is an example of an accused's 'voluntary absence' from the court. The issue of the accused's voluntary absence from court proceedings triggered an intense debate at the ICC, which is the subject of discussion in the next subparagraph.

\subsubsection{The ICC}

The issue of partial in absentia trials has had a colorful history in the context of the ICC. This history goes back to 2013, when the Court in the Kenya situation was faced with some novel requests from the Ruto and Kenyatta Defence teams to compel the Court to excuse their clients from constant presence in the courtroom. Although the prohibition of total in absentia trials is an established rule in the ICC legal system, the possibility of conducting partial in absentia trials had not been laid down in the ICC legal framework. It is, however, obvious that the Rome Statute is not an exhaustive legal text, because in 1998 the delegates to the Rome Conference were not able to predict everything that could possibly happen in the future. As Singh observed: 'it is impossible even for the most imaginative legislature to forestall exhaustively situations and circumstances that may emerge after enacting a statute where its application may be called for., ${ }^{117}$ Judicial interpretation of the Statute's provisions may therefore be called for, in light of developments, insights and needs over time. That is why Bennion, a British barrister, submitted that a court 'has a certain degree of delegated legislative power. ${ }^{118}$

3.2.1.1 Developments in the Ruto and Kenyatta Cases. Before legally analyzing the developments in the cases concerning Ruto and Kenyatta relating to in absentia, an overview of the earlier developments in these cases are given first. On 26 November 2009, the ICC Prosecutor requested authorization to open an investigation in relation to crimes allegedly committed during the 2007-2008 post-election violence in Kenya in which hundreds of people were killed. ${ }^{119}$ On 31 March 2010, Pre-Trial Chamber II authorized the Prosecutor to

${ }^{117}$ P. Singh, Principles of Statutory Interpretation, $8^{\text {th }}$ Edn (India: Wadhwa \& Co, 2001), 45 .

${ }^{118}$ F.A.R. Bennion, Bennion onStatutory Interpretation, $5^{\text {th }}$ edn (London: LexisNexis, 2008), 470.

119 On 15 March 2005, Kenya ratified the Rome Statute, allowing the Court jurisdiction over war crimes, crimes against humanity, and genocide committed by Kenyan nationals or on Kenyan territory after 1 July 2002, the date the Rome Statute entered into force. 
open an investigation into alleged crimes against humanity committed between 1 June 2002 (the date of the Rome Statute's entry into force for Kenya) and 26 November 2009 (the date the Prosecutor filed the request for authorization to start an investigation) in Kenya. ${ }^{120}$ On 8 March 2011, Pre-Trial Chamber II summoned - as an alternative to issuing arrest warrants - three suspects, including Uhuru Muigai Kenyatta and William Samoei Ruto, to appear before the Court, because it found reasonable grounds to believe that they committed the crimes alleged by the Prosecutor. ${ }^{121}$ On 7 and 8 April 2011, Ruto and Kenyatta, respectively, made their initial appearance before the Court in The Hague. The charges against the two accused were subsequently confirmed by the Pre-Trial Chamber. ${ }^{122}$ On 9 July 2012, Trial Chamber V, that is dealing with these cases, set the dates for the commencement of the trials of Ruto and Kenyatta, for 10 and 11 April 2013, respectively. ${ }^{123}$

Nonetheless, before the opening of the trial, a significant event happened. Ruto and Kenyatta were elected as Deputy President and President of Kenya, respectively. This momentous turn of events in their circumstances gave rise to a request to the Chambers by their Defense lawyers to excuse Ruto and Kenyatta from their continuous presence in the courtroom. This request, at first, was made by Ruto's Defense in April 2013 and then followed by Kenyatta's in September 2013. ${ }^{124}$ Both requests were conditionally granted by Chambers V(a) (for Ruto) and V(b) (for Kenyatta). More precisely, the Chambers

${ }^{120}$ Situation in the Republic of Kenya, (Decision Pursuant to Article 15 of the Rome Statute on the Authorization of an Investigation into the Situation in the Republic of Kenya) ICC-01-09/19 (31 March 2010).

${ }^{121}$ Situation in the Republic of Kenya, (Decision on the Prosecutor Application for Summons to Appear For William Samoei Ruto, Henry Kosgey and Arap Sang) ICC-01/09-01/11 (8 March 2011).

122 Prosecutor v. Ruto, Kusgey and Sang, (Decision on the Confirmation of Charges pursuant to Article 61(7)(a) and (b) of the Rome Statute) ICC-01/09-02/ 11(23 January 2012), and Prosecutor v. Kenyatta and Hussein Ali, (Decision on the Confirmation of Charges pursuant to Article 61(7)(a) and (b) of the Rome Statute) ICC-01/09-02/11 (23 January 2012).

${ }^{123}$ Prosecutor v.Kenyatta, (Decision on the Schedule Leading up to Trial) ICC-01/ 09-01/11(9 July 2012), and Prosecutor v. Ruto and Arap Sang, (Decision on the Schedule Leading up to Trial) ICC-01/09-01/11 (9 July 2012).

${ }^{124}$ Prosecutor v. Ruto and Arap Sang, (Defense Request Pursuant to Article 63(1) of the Rome Statute) ICC-01/09-01/11-685 (17 April 2013); Prosecutor v. Kenyatta, (Defense Request for Conditional Excusal from Continuous Presence at Trial) ICC01/09-02/11 (23 September 2013). 
obliged Ruto and Kenyatta to physically attend the proceedings in the courtroom, but only for some important hearings, such as during the opening and closing statements and for 'any other attendance directed by the Chamber. ${ }^{125}$ The Chamber's decision as to Ruto's excusal was objected by the Prosecutor. The Prosecutor thus appealed against the Chamber's decision in favor of Ruto's request on the basis of two issues: Is Rule 134quater, as interpreted by the Chamber when granting an conditional excusal to Mr. Ruto, consistent with Articles 63(1), 21(3) and 27(1) of the Rome Statute; and if so, does it on its own terms permit the Chamber to conditionally excuse Mr. Ruto from presence at trial subject to the conditions in paragraph 79 of the Chamber's written reasons. ${ }^{126}$ Then, on 25 October 2013, the Appeal Chamber reversed the impugned decision. The reason behind the judgment was that in the eyes of the Appeal Chamber the Trial Chamber had interpreted the scope of its discretion to excuse the accused from the presence at the courtroom too broadly and 'effectively making his absence the general rule and his presence an exception. ${ }^{127}$ The Prosecution subsequently also addressed the granted excusal to Kenyatta and requested Trial Chamber $\mathrm{V}(\mathrm{b})$ to reconsider its diction on Kenyatta's excusal. ${ }^{128}$ Therefore, the Chamber reconsidered its decision by reference to the similarity between the reasoning underlying both decisions of Ruto and Kenyatta's requests to be excused. It concluded that 'Mr. Kenyatta will therefore as a general rule have to be present for his trial,' but any further requests by him to be excused from attending parts of the trial will be considered on a case-by-case basis. ${ }^{, 29}$

The success of the Prosecutor to alter the situation against the acting heads of Kenya did not put an end to this story. Kenya took advantage of the twelfth session of the Assembly of States Parties (ASP) to the ICC which was held in November 2013. Influenced by

${ }^{125}$ Decision on Mr. Ruto's Request for Excusal form Continuous Presence at Trial (n 137 above).

${ }^{126}$ Prosecutor v. Ruto and Arap Sang, (Prosecution's Application for Leave to Appeal the 'Decision on Mr Ruto's Request for Excusal from Continuous Presence at Trial) ICC-01/09-01/11 (24 February 2014), para. 1.

127 Judgment on the Appeal of the Prosecutor against the Decision of Trial Chamber V(a) on 18 June 2013 entitled 'Mr. Ruto's Request for Excusal from Continuous Presence at Trial' (n 109 above), para. 63.

${ }^{128}$ Prosecutor v. Kenyatta, (Prosecutor's Motion for Reconsideration of the 'Decision on Defence Request for Conditional Excusal from Continuous Presence at Trial' and in the Alternative Application for Leave to Appeal) ICC-01/09-02/11-837 (28 October 2013).

129 Ibid., para. 16. 
Kenya and the support from other delegates of State Parties, the ASP adopted Rule134quater by consensus and two other amendments to the RPE, addressing the meaning, scope and application of Article 63(1), namely Rules $134 b i$ is and 134ter. ${ }^{130}$ These amendments and incorporations are prominent episodes in the life of the ICC. Rules 134 bis and 134ter contain lenient policies to encourage the persons charged by the ICC to attend before the Court voluntarily, because they address only the summoned accused and do not include those who are under an arrest warrant. Rule 134bis provides that an accused can be present through video technology upon application to and at the discretion of the Trial Chamber. This Rule reads ' 1 . An accused subject to a summons to appear may submit a written request to the Trial Chamber to be allowed to be present through the use of video technology during part or parts of his or her trial.' It means that in the eyes of the Court, as discussed before, the in absentia trial is not necessarily related to the accused's mere physical presence in the courtroom. It rather refers to what had already been accepted by the STL: Rule 104 of the STL RPE states: 'Proceedings shall not be in absentia if an accused appears before the Tribunal in person, by video-conference or by counsel appointed or accepted by him.' Also, Rule 134ter sets out the principles and procedures governing a Trial Chamber to exercise its discretion where the accused requests excusal from the presence in a part or parts of the proceedings on the basis of 'exceptional circumstances' that justify such an absence. To grant such a request, in accordance with Rule 134ter, the Trial Chamber shall be satisfied that 'alternative measures, including changes to the trial schedule or a short adjournment would be inadequate,' 'the accused has explicitly waived his or her right to be present at trial' and 'the rights of the accused will be fully ensured in his or her absence.' Rule 134ter(3) reaffirms that an exemption is an exception and any absence 'must not become the rule.' Besides this Rule, the ASP expressed its consensus view through Rule 134quater that the accused persons who are 'mandated to fulfill extraordinary public duties at the highest national level' can submit a written request to the Trial Chamber to be excused and be represented by counsel only, their request should be granted where it is in the interest of justice. These two rules share a substantive feature and that is that any excusal from the presence at trial should be an exception and not a rule and should be justified on the basis of the existence of exceptional

${ }^{130}$ See ICC Assembly of States Parties Resolution (ASP/12/Res.7), adopted on 27 November 2013 at 12th Plenary Meeting. 
circumstances. However, from an evidentiary perspective, there is a prominent distinction between these rules. Undertaking extraordinary public duties is presumed as such exceptional circumstances; it means that there is an evidentiary presumption in favor of those defendants who are undergoing extraordinary public duties at their countries that exempt them from proving that their situation is exceptional. This thus means that the amended rules draw a distinction between different defendants on the basis of their public status.

Subsequent to these amendments, in the last days of 2013, the Defense of Ruto submitted a request to excuse himself from attendance at trial, not just a partial excusal but rather a blanket excusal. ${ }^{131}$ In light of this request, on 15 January 2014, pursuant to Chamber V(a)'s order, a 'status conference' was held to discuss the request and other matters related to the trial proceedings. During the status conference, the Chamber, by oral ruling, decided to conditionally excuse Mr. Ruto from being present at trial. Afterwards, on 18 February 2014, the Chamber issued the written reasons beyond its oral ruling. ${ }^{132}$ The Chamber had assessed all legal requirements in accordance with Rule 134quater and came to the conclusion that they all were met and therefore had granted Ruto a conditional refusal. As to the nature of the official status of the accused, the Chamber submitted that although it agreed that 'not every duty at the highest national level is an extraordinary one', ${ }^{133}$ 'the Chamber is of the view that when it is reasonably expected, based on the Constitution of Kenya, that the accused is highly likely to be frequently required to fulfill extraordinary duties at the highest national level, the proper accommodation of these duties is to excuse him from presence at trial, but with limitations. Indeed, such was the intention of the ASP, which consciously omitted from Rule 134quater of the Rules the requirement of a case-by-case ruling. ${ }^{, 134}$

Nonetheless, the Chamber avoided granting an unconditional excusal, because in the eyes of the Chamber such an unconditional excusal is incompatible with the interest of justice. The interest of

${ }^{131}$ Prosecutor v. Ruto and Arap Sang, (Defense Request pursuant to Article 63(1) of the Rome Statute and Rule 134quater of the Rules of Procedure and Evidence to excuse Mr. William Samoei Ruto from Attendance at Trial) ICC-01/09-01/1116 (16 December 2013).

${ }^{132}$ Prosecutor v. Ruto and Arap Sang, (Reasons for the Decision on Excusal from the Presence at Trial under Rule 134quater) ICC-01-09-01/011 (18 February 2014).

133 Ibid., para. 64.

${ }^{134}$ Ibid., para. 65. 
justice is a compound notion, encompassing different interests, such as the interest of the Court, the interest of the victims, the interest of the accused and the interest of the international community. That is why the Chamber has to keep a balance between these distinct interests to satisfy the interest of justice requirement. In the words of the Chamber: 'The Chamber is of the view that the continuous absence of Mr Ruto throughout the entire remainder of the trial may indeed be incompatible with the interests of justice, given the active participation of victims in the proceedings. The Chamber is thus persuaded that limitations, listed in the Oral Ruling, should attach to the excusal in order to minimize the adverse effects which the absence of the accused may produce. ${ }^{, 135}$ On the basis of adopting such an approach, 'the Chamber decided to conditionally excuse Mr Ruto from presence at trial pursuant to Rule 134quater of the Rules.'

Upon the achievements gained by Ruto's Counsel, the Defense for Kenyatta filed a request before the Court to excuse Kenyatta pursuant to Rule 134quater from attending the status conference that had already been scheduled for 8 October 2014 to discuss cooperation matters between the ICC and Kenya. ${ }^{136}$ However, this request was not granted by the Court and it announced that Kenyatta would need to be present at the status conference. ${ }^{137}$ Therefore, in October 2014, Kenyatta became the first acting head of state who appeared before the ICC. However, due to a lack of evidence against the accused, which - according to the Prosecutor - was due to non-cooperation by the Kenyan government to investigate the crimes and unwillingness of witnesses to testify in court due to witness interference, the Prosecutor had to decide, pressured by the Court, to withdraw the charges against Kenyatta. Therefore, the case was closed in December $2014,{ }^{138}$ which led to a lot of critique from different corners,

${ }^{135}$ Ibid., para. 74. See also on this issue: A. Knottnerus, 'The International Criminal Court on Presence at Trial: the (in)validity of Rule 134quater', International Crimes Database, Brief 5, September 2014.

${ }^{136}$ Prosecutor v. Kenyatta, (Defence Request for Excusal from Attendance pursuant to Rule 134 quater or to Adjourn the Status Conference Scheduled for 8 October 2014 and Permit Mr Kenyatta to Attend on a Rescheduled Date by Means of Video-link pursuant to Rule 134 bis) ICC-01/09/-02/11 (25 September 2014).

${ }^{137}$ See http://www.icc.cpi.int/en_menus/icc/press\%20and\%20media/press \%20releases/ Pages/ma166.aspx.

${ }^{138}$ According to the Prosecutor, the withdrawal of the charges does not mean that the case has been permanently terminated. The case can be re-opened, or brought in a different form, if new evidence establishing the crimes and his responsibility for them is discovered. See: ICC, 'Statement of the Prosecutor of the International 
saying that the Court should have referred the matter to the ASP to address the non-cooperation issue. ${ }^{139}$ Now, in the eyes of the critics, the wrong message has been given to States (we will not prosecute when there is no cooperation) and victims of the crimes are the ones mostly affected without any form of justice. ${ }^{140}$

3.2.1.2 Analysis of the Ruto and Kenyatta Cases. How can one evaluate the above developments in the Ruto and Kenyatta cases in light of the issue of partial in absentia trials? As set out before, there are a set of provisions governing the issue of the presence of the accused in the courtroom in the ICC legal system, namely Articles 63(1), 67(1)(d) and 64(2) of the Rome Statute and Rules 134ter, 134 bis and 134quater of the ICC RPE. There is a need for adopting a holistic approach when interpreting these provisions; in other words, the Rome Statute must be read as a whole. This kind of interpretative approach is accepted by the International Court of Justice in one of its advisory opinions: 'It is obvious that the Treaty must be read as a whole and that its meaning is not to be determined merely upon particular phrases which, if detached from the context, may be interpreted in more than one sense. ${ }^{141}$ With respect to the ICC, this interpretative approach means that each provision and part of the Rome Statute must be read and construed in light of other provisions and parts of the Statute in a manner that does not make them contradictory, redundant or inconsistent with each other in the context of the Statute.

It is indisputable that the presence of the accused at trial is a right, which is accorded to the accused by the Rome Statute as laid down in Article 67(1)(d) and as discussed in previous sections. One of the major features of a right is that the right holder is able to waive his right. It is the distinction between rights and obligations. This feature of the right to be present was controversial in the Ruto and Kenyatta

Footnote 138 continued

Criminal Court, Fatou Bensouda, on the withdrawal of charges against Mr. Uhuru Muigai Kenyatta', 5 December 2014.

139 See e.g.: Redress, 'President Kenyatta ICC Case: Kenyan Government Should Account for Impeding Access to Justice and Truth for Thousands of Victims of the Post-Election Violence', 4 December 2014.

${ }^{140}$ Ibid.

${ }^{141}$ Advisory Opinion on Competence of the ILO in regard to International Regulation of the Conditions of the Labor of Persons Employed in Agriculture, 12 August 1922, ICJ (Series B, No 2), 23. 
cases. The Ruto defense believed that their client had an authority to waive his right. They argued that the presence at trial is merely a right of the accused. On the basis of this argument, they requested the Chamber to excuse Ruto from attending his hearings. However, this viewpoint is not accepted by adopting a holistic approach to the Statute. Besides Article 67(1)(d), there is another provision in the Rome Statute that must be considered, namely Article 63(1), according to which 'the accused shall be present during the trial.' The defense claimed that the latter right only reaffirms the right of the accused to be present, enshrined in Article 67(1)(d) of the Rome Statute. ${ }^{142}$ Yet, if there was a similarity between both Articles it would result in redundancy of one of them. It is obvious that such a result is not accepted, especially in the context of the Rome Statute, which must be as comprehensive as possible, because it is a legal text of a permanent institution. Indeed, there is no room for redundancy and repetition. The counsel's viewpoint drew the same criticism from the Trial Chamber. ${ }^{143}$ In the eyes of the Chamber Article 63(1) of the Rome Statute contains an issue, independent from the content of Article 67(1)(d).

What does Article 63 of the Rome Statute imply? Article 63(1) provides that there is an obligation upon the accused to be present at trial. In fact, the presence of the accused at trial is both his right and his obligation. For this reason, the accused is not allowed or entitled to waive his right and become absent at trial only on his own will. Presence at trial is not a mere right, but it is a hybrid one. In fact, it is a coin with two sides; from one side it is a right, enshrined in Article 67(1)(d), and from the other side it is an obligation, set out in Article 63(1). Article 63(1) has a normative language; it uses the word 'shall' and it clearly implies an obligation

Each obligation must be justified and have a solid basis. The duty to be present at the court is derived from the authority of a court to have 'judicial control' over the case being tried. ${ }^{144}$ Each court has an implied power to impose restrictions on the whereabouts and time of the accused, who is under investigation of that court. Without such a power, a court is not able to proceed with its investigations. The 'functional necessity' doctrine also supports this authority of courts.

${ }^{142}$ Defense Request Pursuant to Article 63(1) of the Rome Statute (n 124 above), para. 5 .

${ }^{143}$ Decision on Mr. Ruto's Request for Excusal from Continuous Presence at Trial (n 40 above), para. 39.

144 Ibid., para. 42. 
The functional necessity concept asserts that an entity shall be entitled to do what is strictly necessary for the exercise of its functions in the fulfillment of its purpose. ${ }^{145}$ From such a perspective, one can asserts that the court is empowered with such an authority.

It was mentioned that Article 63(1) of the Rome Statute contains an obligation imposed on the accused. Now a question arises "whether the scope of this obligation is limited only to the accused'? In the Ruto case, the Prosecution asserted that the scope of this obligation goes beyond the accused and embraces the Court as well. The existence of such an obligation implies that the Court has not got any discretion to excuse the accused from the presence in the courtroom; even the accused waives his right to be present. On the basis of this claim, the Prosecutor appealed against the Trial Chamber decision in favor of Ruto's request to be excused from the continuous presence. However, this assertion was not accepted by the Appeal Chamber. The Appeal Chamber found in its judgment of 25 October 2013 that 'article 63(1) of the Statute does not operate as an absolute bar in all circumstances to the continuation of trial proceedings in the absence of the accused. ${ }^{, 146}$ There are some reasons supporting the non-existence of such an obligation upon the Court. Firstly, as mentioned above, the basis of the obligation arising from Article 63(1) is the idea of 'judicial control.' This justification is only related to the accused. Secondly, if the drafters of the Statute intended to impose this obligation they could use a different language for Article 63(1) and worded it in the prohibitory model, like Rule 60(1) of the Rules of Procedure and Evidence of the Special Court for Sierra Leone which provides that 'an accused may not be tried in his absence.' Lastly, the Trial Chamber argued that an interpretation that imposes the duty on the Chamber fosters 'the judicial inefficiency by constraining the Chamber to stop the trial on every occasion that the accused is unable with good reason to be present during the trial although he consents that the trial may proceed in his absence. ${ }^{147}$ The Chamber adduced

${ }^{145}$ P.H.F. Bekker, The Legal Position of Intergovernmental Organizations: A Functional Necessity Analysis of Their Legal Status and Immunities (Leiden: Brill, 1994), 39.

146 Judgment on the appeal of the Prosecutor against decision of trial Chamber V(a) of 18 June 2013 entitled 'Decision on Mr. Ruto's request for Excusal from Continuous Presence at Trial' (n 109 above), para. 55.

${ }^{147}$ Decision on Mr. Ruto's Request for Excusal from Continuous Presence at Trial (n 40 above), para. 44. 
the Bemba case in which his trial continued while he was absent from it for some hours due to his health conditions. ${ }^{148}$

Hence, the presence at trial has got a twofold nature. From one side, it is a right of the accused, which prohibits the holding of in absentia trials. From the other side, it is an obligation upon the accused, which obliges him to be present at trial, even though he waives his right to be present. This mixed nature leads to the following consequences: the accused is not allowed to be absent at trial by waiving his right, unless the Court accepts his request. And also, the Court it is not allowed to hold an in absentia trial unless the accused explicitly waives his right to be present. This complex interaction between the right of the accused and the discretion of the court is well enshrined in the recent amendments. According to the amendments, the Trial Chamber of the Court has discretion to excuse the accused from part of his trial; the existence of an explicit waiver of right to be present is a prerequisite for exercising of such discretion.

Furthermore, the Counsel for Mr. Ruto, as part of the oral submission in support of his application, argued that one reason that recommended the excusal he sought for his client was that it will generate judicial precedent that will make it easier in the future for leaders of states to stand trial before this court while still fulfilling their obligations of governance at home. ${ }^{149}$ Although the Trial Chamber rejected this normative argument, this argument provided a context for the amendments to the Rules.

What happened in the Ruto case exemplifies the dilemma of 'cooperation versus justice.' Although the judicial pillar of the Court, namely its Chambers, consider the issue of the accused's presence in the courtroom from the perspective of justice and for that reason laid a high threshold which did not include the duties and positions of the acting head of states, the cooperation and external pillar of the court, namely the ASP amended the Rules in accordance with the real facts on the ground, justifying giving priority to the cooperation issue. From this perspective, the ASP obliges the Chambers of the Court to grant the excusal request from the accused who are acting in high national level state positions to receive cooperation from states and encourage the defendants to cooperate with the Court.

\footnotetext{
148 Ibid.

149 Ibid., para. 29.
} 


\section{FINAL REMARKS}

Coming back to this contribution's main question on the permissibility of total and partial in absentia trials before international criminal tribunals it is submitted that, by making a conceptual distinction between different types of in absentia trials, total in absentia trials should be prohibited in international criminal law, whereas partial in absentia trials can be accepted in certain circumstances.

From a practical and normative perspective total in absentia trials should be prohibited. Total in absentia trials imply that the outcome of such trials are not enforceable on the accused due to his absence. In addition, in the case of total in absentia trials a retrial would be necessary if the accused is later apprehended. In such a situation, in absentia trials can be seen as time and money consuming mechanisms. Furthermore, when assessing the in $a b$ sentia trials in light of the human rights standards, such as the accused's right to a fair trial, the same conclusion must be reached. However, this conclusion does not leave aside the option for international criminal tribunals to opt for procedures in absentia along the lines of Rule 61 of the ICTY/ICTR RPE and Article 61 of the Rome Statute. These are pre-trial mechanisms that offer various advantages in the absence of total in absentia trials proper, including giving victims of international crimes the opportunity to participate and testify in court.

On the contrary, partial in absentia trials could be accepted in some circumstances, including where the accused displays disruptive behavior in the courtroom or is voluntarily absent. In these situations, the fair trial principle is not necessarily violated. The presence of the accused at the criminal proceeding is far and foremost a right of the accused. Yet, being a right, the presence at trial is derogable. Therefore, if the accused continuously disrupts the proceedings or voluntarily chooses to be absent, the court has discretion to excuse the accused from presence at trial in exceptional circumstances. In the eyes of the ICC, executing extraordinary sovereign functions is an example of such circumstances, which, however, provides the accused a big advantage: the accused does not have the burden of proving that his situation is exceptional. This can be interpreted as a privilege that is given by the Court to defendants who are in the highest state positions within their country while encouraging the accused to cooperate with the Court. This is a very far-reaching rule and, as seen in 
the Kenyatta case, did not lead to the accused's cooperation with the Court. The Court should be vigilant when it comes to determining whether a 'voluntary absence' situation is an exception to the rule (to be present at trial) and not treat categories of defendants differently.

Open Access This article is distributed under the terms of the Creative Commons Attribution 4.0 International License (http:// creativecommons.org/licenses/by/4.0/), which permits unrestricted use, distribution, and reproduction in any medium, provided you give appropriate credit to the original author(s) and the source, provide a link to the Creative Commons license, and indicate if changes were made. 